\title{
Assessment of Factors Affecting Default Risk in Project Finance: A Case of Omo Micro Finance, Hawassa Branch
}

\author{
Kassahun Bekele Tegene \\ Department of Accounting and Finance, College of Business and Economics, Hawassa University, Hawassa, \\ Ethiopia
}

\begin{abstract}
This study assesses factors that Affecting Default Risk in Project Finance: A Case of Omo Micro Finance, Hawassa Branches. Primary data were used in the study. The required data were collected from 338 project finance beneficiaries of Omo Micro Finance institutions and these respondents selected by adopting a simple random sampling technique. Both qualitative and quantitative methods were used. The data collected through questionnaire were analyzed using SPSS software version 20. Descriptive statistics such as frequency and percentage were applied. Furthermore, inferential statistics Chi-square and binary logistic regression were used to identify major factors that affect the default risk. In addition, the data collected through interview were analyzed qualitatively using narrative for triangulation. The findings of the study show that $57 \%$ of borrowers in the study area did not repay the amount of money they borrowed as per credit schedules. The major factors that affect the default risk were sex of the borrower, educational level, family size, advisory visit, time lines of loan, repayment period, borrowing experience and training. The study therefore recommends that the stakeholders in the microfinance sector should ensure that the loan borrowers have access to adequate relevant technical training and follow-up in entrepreneurial microfinance businesses.
\end{abstract}

Keywords: Default risk, Institution, Loan, Omo Micro Finance, Project Finance,

DOI: $10.7176 /$ RJFA/11-11-02

Publication date:June 30th 2020

\section{Introduction}

Project financing is the raising of funds on a limited-recourse or non-recourse basis to finance an economically separable capital investment project in which the providers of fund look primarily to the cash flow from the project as the source of funds to service their loans (Zinat, 2010). It is an innovative financial technique that aims to fund the investment project based on the basis of Economic and Financial characteristics of the project itself, rather than on indebtedness capacity of the project promoter (Neila, 2012).

Hence, the ability of the project lenders to recoup the advancements and interest thereon depend substantially on the performance of the project. This typically involves assessing the technical aspects of the project as well as its economic projections. Project Finance thus involves a degree of sophistication in credit analysis that extends beyond normal loans. While lenders would engage their own experts to evaluate the feasibility study submitted by the borrower, lenders must be capable of evaluating the technical and financial projections, as well as the assumptions used in their studies (Enzo, 2012).

In Ethiopia, as in many developing countries, the growing demand of investment in agriculture, industry, construction, hotel and tourism, energy, transportation and housing requires huge amount of funds to be invested. Reports indicate a growing demand of project loans at an increasing rate (OMFI, 2016). For such increasing demand of project loan, Omo Micro Finance Institution (OMFI) as the largest bank in the country should be able to finance such projects in order to be benefited from such opportunities and contribute to the country's growth and transformation plan.

Microfinance institutions were established to fill the gap of scarce finance resources by providing funds to the poor and lower income group to alleviating poverty and enhance their business activities. Different approaches have been employed in alleviating poverty; the one is provision of credit for targeted poor. Credit is considered to be an essential input to increase productivity (Nawai and Shariff, 2010).

The primary objective of MFIs is to provide financial services (credit and saving) to the poor in order to relieve financial constraints and help alleviate poverty. Microfinance institutions offer loans mostly to urban and rural peoples who cannot afford collaterals to get loans from banks. Financial services in Ethiopia are characterized by a high urban concentration (Facet, 2013). To fill this gap microfinance institutions provide credit to the poor, who lack access of formal credit from financial institutions.

However, micro-finance sector currently face challenges of loan repayment (defaults) by clients. The poor loan controlling system causes serious challenge to most microfinance institutions. According to Duy and Nam (2016) Loan default may also deny new applicants access to credit as the bank's cash-flow management problems augment in direct proportion to the increasing default problem. The credit scheme Omo Micro Finance Institution was mainly mobilizing savings from its client and giving loan to borrowers. This loan was threatened by defaults and low repayment performances due to different behaviors of the borrowers. Consequently the institution may 
face shortage of finance to lend to new borrowers (Omo Micro Finance Institution [OMFI], 2016).

Therefore, the researcher motivated to identify the factors affecting default risk in project finance: a case of Omo Micro Finance, Hawassa branches.

\section{MATERIAL \& METHODS}

\section{Description of the Study Area}

This study was conducted in Hawassa City. Hawassa is located in Southern Nations Nationalities and Peoples Regional state on the shores of Lake Hawassa in the Great Rift Valley and served as the capital of the SNNPRS and Sidama Zone. It is situated at distance of $275 \mathrm{~km}$ south of Addis Ababa. The city lays on the Trans-African High way-4 an international road that started from Cairo (Egypt) to Cape Town (South Africa). Geographically the city lays between $6^{0} 54^{\prime}-7^{0} 60^{\prime}$ latitude north and $38^{\circ} 48^{\prime}-38^{0} 33^{\prime}$ longitude east and the area is 157.25 Sq.Kms which is divided in to eight sub cities and 32 kebeles (Hawassa City Administration Finance and Economic Development Department (HCAFDD), 2016).

Concerning the climatic condition of the study area, the temperature varies from $6^{\circ} \mathrm{c}$ to $34^{\circ} \mathrm{c}$. The average annual temperature is $24^{\circ} \mathrm{c}$ and average rain fall is $933.4 \mathrm{~mm}$. Hawassa city is bounded by Lake Hawassa in the West, Oromia Region in the North, Wondo Gent Woreda in the East and Shebedino woreda in the South. Based on the 2007 National Population and Housing Census, the current projected population of Hawassa is 343,175 inhabitants, of whom 169,677 were males and the rest 160,057 females (Bureau of Finance and Economic Development [BoFED], 2016). Financial services were available to the people of Hawassa city through government and privately owned financial institutions. These are Commercial bank of Ethiopia, Sidama Micro Finance Institution (SMFI) and OMFI

\section{Research Approach}

In this study the researcher was used both quantitative and qualitative approach. The use of both methods also ensures that the data was effectively interpreted and analyzed using the statistical analysis, descriptive figures as well as the narrative. According to Creswell (2009) three types of research approach which are familiar to business and social science research are quantitative, qualitative and mixed methods approach. But, based on different researchers (Leedy and Ormrod, 2005; McKerchar, 2010 and Creswell, 2009) recommendations, mixed method approach will be adopted because; it was enable one approach to inform another approach in the interpretation of the overall results.

\section{Research Design}

The study employed cross sectional research design with quantitative and qualitative methods. The quantitative aspect of the data was focus on description of socio economic variables, loan and related variables, and business related variables and analysis of relationship among the dependent and independent variables of OMFI for the study.

\section{Data Source and Types}

The study employed primary sources of data. The primary sources were collected from project finance beneficiaries of Omo Micro Finance institutions. In addition to primary sources, published and unpublished studies, journal articles and report documents available were perused.

\section{Population and Sampling}

Under this topic, the number of borrowers in Hawassa branch of Omo Microfinance Institution and the representative amount of sample was explained. In addition the types of sampling techniques that the researcher was adopted also explained as follows.

\section{Sample size determination}

To determine the sample size, the information about number of project finance clients who were borrowed from Omo microfinance were taken from Omo Microfinance Institution Hawassa branch borrowers profile list. According to the information obtained from the institution, there are 3263 project finance clients were borrowed. This data is used as benchmark to determine the sample size. The numbers of sample borrowers included for collecting information were determined by using the formula developed by Cochran (1977).

$n_{o}=\frac{Z_{\alpha / 2}^{2} p(1-p)}{d^{2}}=377$ 


\section{Where}

$n=$ the desired sample size

$Z=$ the statistics for the level of confidence (1.96)

$P=$ is the proportion borrowers, who are defaulter (0.57)

$d=$ Marginal error between the population and sample size $(5 \%)$

Since the initial sample size is greater than $5 \%$ of the total population $(5 \% * 3263=164)$, Cochran's (1977) correction formula were used to calculate the final sample size. Accordingly, the calculations are as follows:

$$
n=\frac{n_{o}}{1+\frac{n_{0}}{N}}=338
$$

Therefore, $\mathbf{3 3 8}$ Omo microfinance project finance clients were representative sample for eliciting the required data.

\section{Sampling techniques}

After determining the sample size, the respondents were selected using stratified random sampling technique. Project finance borrowers of the microfinance were stratified in to eight strata and proportional numbers of respondents will be selected from each sub-city using Probability Proportional to Size (PPS) sampling technique. Finally each respondent were selected using simple random sampling technique (lottery method). Proportionate sample size from each stratum

\begin{tabular}{|l|c|c|c|c|c|}
\hline \multicolumn{1}{|c|}{ Sub-city } & $\begin{array}{c}\text { Number of } \\
\text { Defaulters }\end{array}$ & $\begin{array}{c}\text { Sample } \\
\text { Defaulters }\end{array}$ & $\begin{array}{c}\text { Number of } \\
\text { Non- Defaulters }\end{array}$ & $\begin{array}{c}\text { Sample } \\
\text { Non- Defaulters }\end{array}$ & $\begin{array}{c}\text { Total } \\
\text { Sample }\end{array}$ \\
\hline Addis Ketema & 246 & 25 & 252 & 27 & 52 \\
\hline Bahl Adarash & 179 & 19 & 160 & 16 & 35 \\
\hline Haik Dar & 200 & 21 & 136 & 14 & 35 \\
\hline Hawella Tula & 145 & 15 & 72 & 7 & 22 \\
\hline Mehal Ketema & 223 & 23 & 173 & 18 & 41 \\
\hline Menaharia & 303 & 31 & 229 & 24 & 55 \\
\hline Misrak & 299 & 31 & 132 & 14 & 45 \\
\hline Tabor & 270 & 28 & 244 & 25 & 53 \\
\hline \multicolumn{1}{|c|}{ Total } & $\mathbf{1 8 6 5}$ & $\mathbf{1 9 3}$ & $\mathbf{1 3 9 8}$ & $\mathbf{1 4 5}$ & $\mathbf{3 3 8}$ \\
\hline
\end{tabular}

Source: OMFI, 2016

\section{Data Collection Tools and Techniques}

The study employed both qualitative and quantitative tools. The quantitative data was collected through questionnaire and the qualitative data was collected through Key Informant Interviewees (KII).

\section{Method of Data Processing and Analysis}

The data collected through questionnaire was edited, coded and entered into the computer using Statistical Package for Social Sciences (SPSS) Software Version 20. The analysis techniques were performed using descriptive statistics like frequency and percentages. Furthermore, inferential statistics like Chi-square and binary logistic regression was used to identify major factors that affect default in project finance. The secondary data relating to number of borrowers and defaulters were analyzed using average and growth rate. Data collected through interview was analyzed qualitatively using narrative for triangulation.

\section{Model specification}

Appropriate statistical model is determined by the characteristics of variables that the researcher proposed to investigate. Under this study, the dependent variable "default risk" has two possible outcomes "defaulter" and "non-defaulter". Such variables are characterized as dichotomous and these two outcomes are coded 1 and 0 respectively. Therefore, Binary Logistic regressions were adopted. Binary logistic regression makes no assumption about the distribution of the independent variables. The relationship between the predictor and response variables is not a linear function in logistic regression; instead, the logistic regression function is used, which is the log it transformation of $\boldsymbol{p}$ :

$$
\log \left[\frac{p(x)}{1-p(x)}\right]=\alpha+\beta_{1} x_{1}+\beta_{2} x_{2}+\ldots+\beta_{k} x_{k}
$$

Here $\alpha$ is called the "intercept" and $\beta_{1}, \beta_{2}, \beta_{3}$, and so on, are called the "regression coefficients" of $\chi_{1}, \chi_{2}, \chi_{3}$ 
and so on respectively.

Odds Ratio

The odds of some event happening is defined as the ratio of the probability that the event will occur to the probability that the event will not occur. That is, the odd of an event is given by:

$$
\operatorname{odd}(E)=\frac{p(E)}{P(\text { not } E)}=\frac{P(E)}{p(1-E)}
$$

The odds ratio, which is $\operatorname{Exp}(\beta)$, is the factor by which odds (event) changes for a one unit change in $X$. The odds ratio is a measure of effect size, describing the strength of association or non-independence between two binary data values. It is used as a descriptive statistic, and plays an important role in logistic regression. Unlike other measures of association for paired binary data such as the relative risk, the odds ratio treats the two variables being compared symmetrically, and can be estimated using some types of non-random samples.

The estimated odds are simply the ratio of the estimated proportions for the two possible outcomes. If $\hat{P}_{\text {is }}$ the proportion for one outcome, then $1-\hat{P}$ is the proportion for the second outcome:

$$
O D D S=\frac{\hat{P}}{1-\hat{P}}
$$

This is the ratio of the probability of occurrence of an event to the probability of non-occurrence of the event. There are two main uses of logistic regression. The first is the prediction of group membership. Since logistic regression calculates the probability of success over the probability of failure, the results of the analysis are in the form of odds ratio. Logistic regression also provides knowledge of the relationships and strengths among the variables.

\section{Variable descriptions \\ Dependent variable}

Dependent variable is the estimated result of the independent variable being operated and whose value depends on the value of independent or explanatory variables. It measure to demonstrate the effect of the independent variable. In this study the dependent variable is loan repayment (LR) performance of Omo Micro Finance Institution borrowers. For the $\mathrm{n}^{\text {th }}$ borrower (If $1=\mathrm{nLR}$, borrowers repaying loan on time and $0=\mathrm{nLR}$, borrowers not repay loan on time). The borrowers that did not repay the amount of money they borrowed as per credit schedules are considered as defaulters (denoted by is zero) and borrowers that repaid the amount of money they borrowed per credit schedules are considered as non-defaulters denoted by one.

\section{Independent variables}

The independent variable is normally the variable indicative of the value being manipulated or changed and used to explain the dependent variable. For the purpose of this study the researcher has included twelve independent variables assuming that it is best to explain the determinants of default risk of OMF borrowers.

Sex : many researchers argue that female were better payers than male borrowers, taking into consideration their being more entrepreneurial that results from assuming more responsibilities in the internal affairs of a household . But some researchers have found the opposite result. So nothing can be said about the sign of this variable. In this study sex has hypothesized as positive sign.

Age: In this study age was hypothesized a positive impact on repayment performance. Usually at certain level of age limit borrowers get more stability and experience but beyond a certain age limit this variable has negative relationship. This shows as people get older, their ability to effectively use loan and generate income declines, the variable could also have a negative impact. Hence, may have a nonlinear relationship with loan repayment.

Education Level: This variable is expected to have a positive impact on repayment performance in general. Considering normal circumstances, a more educated borrower is expected to use the loan effectively as compared to a less educated one.

Family Size: Define as the total number of household in the family and elsewhere that depend on the borrower for their livelihood. When the number of household increases, the borrower will need more money for satisfy their requirements in addition to the obligation of loan repayment. As a result, he/she may divert the loan to meet the needs of the dependents. Hence we expect this variable to have a negative impact on loan repayment.

Residence of Borrowers: This variable is a dummy capturing the fact that the borrower lives in rural or urban areas. Borrowers in rural areas are predominantly farmers. Loans extended for agricultural purposes are expected to face problem of default because of risk and uncertainty attached to agriculture. In addition, rural areas are limited by difficulty of access, poor quality of infrastructures and limited local markets. Hence this variable is expected a 
negative sign.

Method of Lending: In group lending there might be more group pressure for defaulters than individual lending. In addition, there was a social norm that governs the group members. The group members may feel responsibility for the other group member loan. Therefore, they may put social sanction on the defaulters within the group and enforce them to repay loan. Therefore, group lending has a positive impact on loan repayment.

Alternative source of income: Some borrowers may have other sources of finance before joining loan program, like from agriculture, from trade, from employment in government or private organizations of the borrower and like. Such sources of finance are expected to have positive contribution towards loan performing. However the availability of such sources creates negligence on the part of borrowers in fulfilling their obligation of repayment possibly considering the next loan unnecessary, it may damage repayment performance. The researcher hypothesized the variable has positive sign.

Borrowing experience: If a borrower is a repeat borrower he/she may have acquired more experience on the institution's rules and regulations, and hence could efficiently utilize the loan for the intended purpose. On the other hand since such borrowers may have the feeling that after borrowing and effectively using the loans for a relatively more years they no more need the loan from OCSSCO and may be reluctant in using the loan as per the loan agreement. Hence the sign of this variable cannot be predetermined.

Timeliness of loan release: If loan is not disbursed in time, it is unlikely that it will be diverted to non-intended purposes. Timeliness of loan disbursement is important when loans are used for seasonal activities. They argued that complicated appraisal and approval procedures, which might delay disbursement, influence a program of seasonal loans that use to buy inputs. Further they noted that this could in turn worsen the prospects of repayment by diverting loan to non-intended purpose. Hence a positive sign is expected.

Loan size: If amount of loan released is enough for the purposes intended, it will have a positive impact on the borrower's capacity to repay. On the other hand the amount of loan exceeds what the borrower needs and can handle, it will be more of a burden than help, thereby undermining repayment performance. Also positive or negative sign may be expected.

Repayment Period: If borrowers find the repayment period appropriate, they can utilize the loan proceeds effectively for the intended purpose than those who regard the period of repayment unsuitable. So it is expected a positive sign for this variable.

Advisory Visit: If there is a continuous follow up and supervision visit to evaluate the loan utilization and repayment, this makes borrowers to observe their obligation and improve the proper utilization of the loan thereby improving repayment performance. Therefore it is expect a positive relationship.

Training: Training in proper loan utilization and business management skills so as to invest in profitable business ventures and improve their loan performing should be needed. Because, borrowers with training skills can utilize their capital effectively than those not trained. Therefore, this variable was also found to influence positively and significantly the borrowers' loan performing.

\section{Ethical Consideration}

Due attention was given for the cultural values of the informants and the employees as a whole over the course of the study especially for those who cannot read and write. Similarly, the researcher was taken legal aspects into account. The purpose of the research was explained to the project finance borrowers of Omo Micro Finance Institutions of Hawassa city to make it more formal. Appropriate times were set together with the loan officers and managers of MFI who was the informants of this study, so as not to affect their daily routines schedule. All sensitive information was kept confidential.

\section{Result and Discussion}

In this chapter the main issues of the actual findings which are based on the default risk of borrowers were described. Besides, factors that affect the loan performing of borrowers were identified. 


\section{Default Risk of Omo Micro Finance Borrowers}

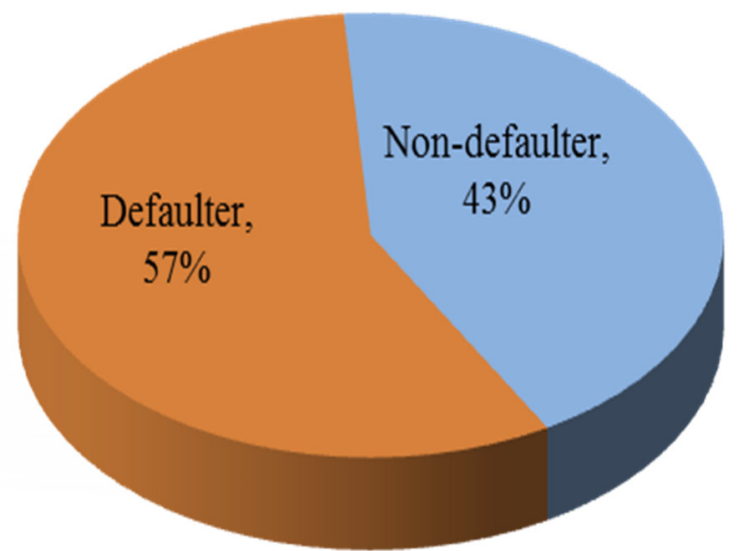

Figure 4.1 Default risk of Omo micro finance borrowers in the study area

As a result showed in Figure 4.1, as high as $57 \%$ of the respondents are defaulters, whereas, $43 \%$ of them are non-defaulters. The key informants also informed that the loan is given to people who cannot afford collaterals to get loans from the main commercial banks and the majority of borrowers use it for consumption and they have no guarantee to repay the amount of money they borrowed as per credit schedules. In connection to this finding Nguta and Huka (2013) argued that the sector is faced with challenges of loan repayment defaults by clients. Individual groups have tried using groups' equity for collaterals which is expected to ensure the revolving of money for the benefits of other individual members of the group. However, loan delinquency has continued to causes serious challenge to most microfinance institutions.

Respondent's source of income

\begin{tabular}{|c|c|c|}
\hline Income source & Frequency(n) & Percentage (\%) \\
\hline Agriculture & 120 & 35.5 \\
\hline Business & 195 & 57.7 \\
\hline Salary & 12 & 3.6 \\
\hline Others Total & 11 & 3.3 \\
\hline
\end{tabular}

Source: Survey data, 2017

Regarding the income sources of borrowers before getting loan, the majority $(57.7 \%)$ of them had income from trade and $35.5 \%$ of them had income from agriculture before getting loan. The key informants informed that the loan helped them to increase their previous income, since their original income is small.

\section{Bivariate Analysis on Factors Affecting the Default Risk of Borrowers}

The association between each explanatory variables and dependent variable was conducted by cross-tabulating them. Independent variables were analyzed one by one using $C h i$-square test in order to identify their relation with the dependent variable. For this purpose, thirteen relevant explanatory variables such as sex, age, educational level, family size, residence, method of lending, income source, borrowing experience, timelines of loan, loan size, repayment period, advisory visit and training were identified through review of literature and tested their relationship with the default risk of borrowers. The bivariate results are presented as follows.

Relationship between sex and default risk

\begin{tabular}{|c|c|c|c|c|c|c|c|}
\hline \multirow[b]{3}{*}{ Sex } & \multicolumn{4}{|c|}{ Default Risk } & & & \multirow{3}{*}{$\begin{array}{c}\chi_{\text {Cal }}^{2} \\
\text { (p-value })\end{array}$} \\
\hline & \multicolumn{2}{|c|}{ Defaulter } & \multicolumn{2}{|c|}{ Non-defaulter } & \multicolumn{2}{|c|}{ Total } & \\
\hline & $n$ & $\%$ & $n$ & $\%$ & $n$ & $\%$ & \\
\hline Male & 180 & 93.3 & 94 & 64.8 & 274 & 81.1 & \multirow{3}{*}{$\begin{array}{c}43.62 \\
(0.000)\end{array}$} \\
\hline Female & 13 & 6.7 & 51 & 35.2 & 64 & 18.9 & \\
\hline Total & 193 & 100 & 145 & 100 & 338 & 100 & \\
\hline
\end{tabular}

Source: Survey data, 2017

According to Table 4.2, sex wise distributions of the sample respondents were assessed and the results found that, $81.1 \%$ of borrowers were male and $18.9 \%$ of them are female. This shows that the number of female borrowers was less than that of male. This is due to the practice of holding the land in the name of male headed households and they get a loan to avail the benefit to develop their farm activities. Also since women are engaged in household activities they might not have adequate time to participate in the other income generating activities which discourage them to get a loan from microfinance institutions. Regarding the relationship between sex and 
default risk, the analysis result shows that more male (93.3) borrowers were defaulters compared to non-defaulters $(64.8 \%)$ whereas, less females $(6.7 \%)$ borrowers were defaulters compared to non-defaulters $(35.2 \%)$. The $C h i$ square results $\left(x^{2}=43.62, \mathrm{p}<0.001\right)$ also revealed that sex and default risk has statistically significant association. This indicates that male were more often defaulters than female.

Relationship between age and default risk

\begin{tabular}{|c|c|c|c|c|c|c|c|}
\hline \multirow{3}{*}{ Age } & \multicolumn{4}{|c|}{ Default Risk } & & & \multirow{3}{*}{$\begin{array}{c}\chi_{\text {Cal }}^{2} \\
\text { (p-value) }\end{array}$} \\
\hline & \multicolumn{2}{|c|}{ Defaulter } & \multicolumn{2}{|c|}{ Non-defaulter } & \multicolumn{2}{|c|}{ Total } & \\
\hline & $n$ & $\%$ & $n$ & $\%$ & $n$ & $\%$ & \\
\hline $18-27$ & 33 & 17.1 & 43 & 29.7 & 76 & 22.5 & \multirow{5}{*}{$\begin{array}{l}18.32 \\
(0.006)\end{array}$} \\
\hline $28-37$ & 78 & 40.4 & 71 & 49.0 & 149 & 44.1 & \\
\hline $38-47$ & 75 & 38.9 & 29 & 20.0 & 104 & 30.8 & \\
\hline $48-57$ & 7 & 3.6 & 2 & 1.4 & 9 & 2.7 & \\
\hline Total & 193 & 100 & 145 & 100 & 338 & 100 & \\
\hline
\end{tabular}

Source: Survey data, 2017

Regarding the relationship between age and default risk, $40.4 \%$ of defaulters and $49 \%$ of non-defaulters were lies between 28-37 age groups. Similarly, 38.9\% of defaulters and 20\% of non-defaulters were lies between 38-47 age groups. According to the cross tabulated survey data analysis the Chi-square value and significance value $\left(x^{2}=18.32, \mathrm{p}<0.01\right)$ indicate that age and default risk has statistically significant association Relationship between educational level and default risk

\begin{tabular}{|c|c|c|c|c|c|c|c|}
\hline \multirow{3}{*}{ Educational level } & \multicolumn{4}{|c|}{ Default Risk } & & & \multirow{3}{*}{$\begin{array}{c}\chi_{\text {Cal }}^{2} \\
\text { (p-value) }\end{array}$} \\
\hline & \multicolumn{2}{|c|}{ Defaulter } & \multicolumn{2}{|c|}{ Non-defaulter } & \multicolumn{2}{|c|}{ Total } & \\
\hline & $n$ & $\%$ & $n$ & $\%$ & $n$ & $\%$ & \\
\hline Didn't attend formal education & 56 & 29.0 & 7 & 4.8 & 63 & 18.6 & \multirow{5}{*}{$\begin{array}{l}42.31 \\
(0.000)\end{array}$} \\
\hline $1-8$ & 67 & 34.7 & 50 & 34.5 & 117 & 34.6 & \\
\hline $9-12$ & 56 & 29.0 & 55 & 37.9 & 111 & 32.8 & \\
\hline College/university & 14 & 7.3 & 33 & 22.8 & 47 & 13.9 & \\
\hline Total & 193 & 100 & 145 & 100 & 338 & 100 & \\
\hline
\end{tabular}

\section{Source: Survey data, 2017}

As presented in Table 4.4, out of the total sampled borrowers, about $29 \%$ of defaulters and $4.8 \%$ of nondefaulter respondents didn't attend formal education. While, $34.7 \%$ of defaulter and $34.5 \%$ of non-defaulter respondents were attended primary education (grade 1-8). Furthermore, the Chi-square analysis $\left(x^{2}=42.31\right.$, $\mathrm{p}<0.001$ ) shows that educational level and default risk has statistically significant association. This indicated that a more educated borrower is expected to use the loan effectively as compared to a less educated one. Therefore, this inferred that educational level has significant impact on default risk. The results of key informant interview revealed that lack of skill to run the business and failure to manage the business properly was a factor for being defaulter.

Relationship between family size and default risk

\begin{tabular}{|c|c|c|c|c|c|c|c|}
\hline \multirow{3}{*}{ Family size } & \multicolumn{4}{|c|}{ Default Risk } & & & \multirow{3}{*}{$\begin{array}{c}\chi_{\text {Cal }}^{2} \\
\text { (p-value) }\end{array}$} \\
\hline & \multicolumn{2}{|c|}{ Defaulter } & \multicolumn{2}{|c|}{ Non-defaulter } & \multicolumn{2}{|c|}{ Total } & \\
\hline & $n$ & $\%$ & $n$ & $\%$ & $n$ & $\%$ & \\
\hline $1-3$ & 28 & 14.5 & 69 & 47.6 & 97 & 28.7 & \multirow{5}{*}{$\begin{array}{c}60.57 \\
(0.000)\end{array}$} \\
\hline $4-6$ & 66 & 34.2 & 51 & 35.2 & 117 & 34.6 & \\
\hline $7-9$ & 57 & 29.5 & 20 & 13.8 & 77 & 22.8 & \\
\hline $10-12$ & 42 & 21.8 & 5 & 3.4 & 47 & 13.9 & \\
\hline Total & 193 & 100 & 145 & 100 & 338 & 100 & \\
\hline
\end{tabular}

Source: Survey data, 2017

Regarding the relationship between family size and default risk, about $47.6 \%$ of non-defaulter respondents and $14.5 \%$ of defaulter respondents had $1-3$ family size. However, $21.8 \%$ of defaulter respondents and $3.4 \%$ of non-defaulter respondents had 10-12 family size. The $C h i$-square value $\left(x^{2}=60.57, \mathrm{p}<0.001\right)$ indicates that family size and default risk has statistically significant association.

Micro finance related factors that significantly contribute to the occurrence of nonperforming loan.

The goals of microfinance institution as development organizations is to service the financial needs of un-served or underserved markets as a means of meeting development objectives such as to create employment, reduce poverty, help existing business grow or diversify their activities, empower women or other disadvantaged 
population groups (poor people or low income people) and encourage the development of new business. In short, microfinance institutions have been expected to reduce poverty, which is considered as the most important development objective (Arsyad 2005). This topic deals withMicro finance related factors that significantly contribute to the occurrence of nonperforming loan and discussed as follows.

Relationship between residence and default risk

\begin{tabular}{|c|c|c|c|c|c|c|c|}
\hline \multirow{3}{*}{ Borrowers Residence } & \multicolumn{4}{|c|}{ Default Risk } & & & \multirow{3}{*}{$\begin{array}{c}\chi_{\text {Cal }}^{2} \\
\text { (p-value) }\end{array}$} \\
\hline & \multicolumn{2}{|c|}{ Defaulter } & \multicolumn{2}{|c|}{ Non-defaulter } & \multicolumn{2}{|c|}{ Total } & \\
\hline & $n$ & $\%$ & $n$ & $\%$ & $n$ & $\%$ & \\
\hline Urban & 177 & 91.7 & 112 & 77.2 & 289 & 85.5 & \\
\hline Rural & 16 & 8.3 & 33 & 22.8 & 49 & 14.5 & 13.98 \\
\hline Total & 193 & 100 & 145 & 100 & 338 & 100 & \\
\hline
\end{tabular}

Source: Survey data, 2017

Table 4.6 shows that, more urban $(91.7 \%)$ borrowers were defaulters compared to non-defaulters $(77.2 \%)$, whereas less rural $(8.3 \%)$ borrowers were defaulters compared to non-defaulters $(22.8 \%)$. Furthermore, the Chisquare result ( $x^{2}=13.98, \mathrm{p}<0.001$ ) also revealed that residence and default risk has statistically significant association. This indicates that urban borrowers were more often defaulters than rural borrowers. Since rural borrowers have multidisciplinary income than urban borrowers.

Relationship between advisory visit and default risk

\begin{tabular}{|c|c|c|c|c|c|c|c|}
\hline \multirow{3}{*}{ Advisory visit } & \multicolumn{4}{|c|}{ Default Risk } & & & \multirow{3}{*}{$\begin{array}{c}\chi_{\text {Cal }}^{2} \\
\text { (p-value) }\end{array}$} \\
\hline & \multicolumn{2}{|c|}{ Defaulter } & \multicolumn{2}{|c|}{ Non-defaulter } & \multicolumn{2}{|c|}{ Total } & \\
\hline & $n$ & $\%$ & $n$ & $\%$ & $n$ & $\%$ & \\
\hline No & 97 & 50.3 & 41 & 28.3 & 138 & 40.8 & \\
\hline Yes & 96 & 49.7 & 104 & 71.7 & 200 & 59.2 & $(0 \Omega 0 \Omega)$ \\
\hline Total & 193 & 100 & 145 & 100 & 338 & 100 & $(0.000)$ \\
\hline
\end{tabular}

Source: Survey data, 2017

As it is shown in Table 4.7, the majority (71.7\%) of non-defaulter respondents and $49.7 \%$ of defaulter respondents responded that they visited by advisors while, $50.3 \%$ of defaulter respondents and $28.3 \%$ of nondefaulter respondents did not visited by advisors.From the cross tabulated analysis the Chi-square value and significance value $\left(x^{2}=16.56, \mathrm{p}<0.001\right)$ also indicated that advisory visit has statistically significant association with default risk. The key informants informed that the purpose of supervision or follow-up is, to enable borrowers to improve their efficiency in business implementation and loan utilization that improves income and default risk. If there is continuous follow up and supervisions to evaluate the loan utilization and repayment, this makes borrowers to observe their obligation and improve the proper utilization of the loan thereby improving default risk. Relationship between method of lending and default risk

\begin{tabular}{|c|c|c|c|c|c|c|c|}
\hline \multirow{3}{*}{ Method of lending } & \multicolumn{4}{|c|}{ Default Risk } & \multirow{2}{*}{\multicolumn{2}{|c|}{ Total }} & \multirow{3}{*}{$\begin{array}{c}\chi_{\text {Cal }}^{2} \\
\text { (p-value })\end{array}$} \\
\hline & \multicolumn{2}{|c|}{ Defaulter } & \multicolumn{2}{|c|}{ Non-defaulter } & & & \\
\hline & $n$ & $\%$ & $n$ & $\%$ & $n$ & $\%$ & \\
\hline Group & 153 & 79.3 & 118 & 81.4 & 271 & 80.2 & \multirow{3}{*}{$\begin{array}{c}\mathbf{0 . 2 3} \\
(0.631)\end{array}$} \\
\hline Individual & 40 & 20.7 & 27 & 18.6 & 67 & 19.8 & \\
\hline Total & 193 & 100 & 145 & 100 & 338 & 100 & \\
\hline
\end{tabular}

Source: Survey data, 2017

According to the analysis result in Table 4.8 , about $81.4 \%$ of non-defaulter respondents and $79.3 \%$ of defaulter respondents responded that they received the loan in group. However, $20.7 \%$ of defaulter respondents and $18.6 \%$ of non-defaulter respondents responded that they received the loan individually. Additionally, the Chisquare value $\left(x^{2}=0.23, \mathrm{p}>0.05\right)$ indicates that lending method and default risk has no statistically significant association. Key informant interview indicated that in group lending methodology respondents had the chance to get loan easily without formal collateral and personal guarantee, joint liability of group members used as collateral. If one group member defaults the other group members makes up for the re-payment amount. They further added that the repayment performance of group lending has been found to be affected by the weekly sales and distance between the members. 
Relationship between timelines of loan and default risk

\begin{tabular}{|c|c|c|c|c|c|c|c|}
\hline \multirow{3}{*}{ Timelines of loan } & \multicolumn{4}{|c|}{ Default Risk } & & & \multirow{3}{*}{$\begin{array}{c}\chi^{2} \text { Cal } \\
\text { (p-value })\end{array}$} \\
\hline & \multicolumn{2}{|c|}{ Defaulter } & \multicolumn{2}{|c|}{ Non-defaulter } & \multicolumn{2}{|c|}{ Total } & \\
\hline & $n$ & $\%$ & $n$ & $\%$ & $n$ & $\%$ & \\
\hline Delay & 154 & 79.8 & 87 & 60.0 & 241 & 71.3 & \multirow{3}{*}{$\begin{array}{l}\mathbf{1 5 . 8 5} \\
(0.000)\end{array}$} \\
\hline Timely release & 39 & 20.2 & 58 & 40.0 & 97 & 28.7 & \\
\hline Total & 193 & 100 & 145 & 100 & 338 & 100 & \\
\hline
\end{tabular}

Source: Survey data, 2017

Respondents were also asked about timelines of loan and found out that the majority $(79.8 \%)$ of the defaulter respondents and $60 \%$ of non-defaulter respondents responded that the timelines of loan were delayed. In contrarily, $40 \%$ of non-defaulters and $20.2 \%$ of defaulters' responded as the loan released timely. The Chi-square analysis $\left(x^{2}=15.85, \mathrm{p}<0.001\right)$ shows that timelines of loan and default risk has statistically significant association. Therefore, it can be inferred that timelines of loan has remarkable impact on borrowers loan performing. The results of key informant interview revealed that timeliness of loan disbursement is important when loans are used for seasonal activities. They argued that complicated appraisal and approval procedures might delay loan disbursement. It influences a program of seasonal loans that use to buy inputs. Further they noted that this could in turn worsen the prospects of repayment by diverting loan to non-intended purpose.

Relationship between loan size and default risk

\begin{tabular}{|c|c|c|c|c|c|c|c|}
\hline \multirow{3}{*}{ Loan size in birr } & \multicolumn{4}{|c|}{ Default Risk } & & & \multirow{3}{*}{$\begin{array}{c}\chi^{2} \text { Cal } \\
\text { (p-value) }\end{array}$} \\
\hline & \multicolumn{2}{|c|}{ Defaulter } & \multicolumn{2}{|c|}{ Non-defaulter } & \multicolumn{2}{|c|}{ Total } & \\
\hline & $n$ & $\%$ & $n$ & $\%$ & $n$ & $\%$ & \\
\hline$<5000$ & 70 & 36.3 & 63 & 43.4 & 133 & 39.3 & \multirow{5}{*}{$\begin{array}{c}\mathbf{6 . 9 6} \\
(0.073)\end{array}$} \\
\hline $5000-30000$ & 113 & 58.5 & 67 & 46.2 & 180 & 53.3 & \\
\hline $30001-55000$ & 8 & 4.1 & 10 & 6.9 & 18 & 5.3 & \\
\hline$>55000$ & 2 & 1.0 & 5 & 5.4 & 7 & 2.1 & \\
\hline Total & 193 & 100 & 145 & 100 & 338 & 100 & \\
\hline
\end{tabular}

Source: Survey data, 2017

Regarding the relationship between loan size and default risk, $58.5 \%$ of defaulter and $49.2 \%$ of non-defaulter get loan size 5000-30000 birr. Likewise, $1 \%$ of defaulters and 5.4\% of non-defaulters borrowed more than 55000 birr. According to the cross tabulated survey data analysis, the $C h i$-square value and significance value $\left(x^{2}=6.96\right.$, $\mathrm{p}>0.05$ ) indicate that loan size and default risk has no statistically significant association. It means the amount of money borrowed had no influence to repay the amount of money they borrowed per credit schedules.

\section{Causes of project loan default due to borrower specific factors in OMF}

Under this topic an assessment was made regarding causes of project loan default due to borrower specific factors in OMF; the results are shown in Table 4.11-4.13.

Relationship between repayment period and default risk

\begin{tabular}{|c|c|c|c|c|c|c|c|}
\hline \multirow{3}{*}{ Repayment period } & \multicolumn{4}{|c|}{ Default Risk } & & & \multirow{3}{*}{$\begin{array}{c}\chi_{\text {Cal }}^{2} \\
\text { (p-value) }\end{array}$} \\
\hline & \multicolumn{2}{|c|}{ Defaulter } & \multicolumn{2}{|c|}{ Non-defaulter } & \multicolumn{2}{|c|}{ Total } & \\
\hline & $n$ & $\%$ & $n$ & $\%$ & $n$ & $\%$ & \\
\hline Not suitable & 141 & 73.1 & 67 & 46.2 & 208 & 61.5 & \multirow{3}{*}{$\begin{array}{l}25.22 \\
(0.000)\end{array}$} \\
\hline Suitable & 52 & 26.9 & 78 & 53.8 & 130 & 38.5 & \\
\hline Total & 193 & 100 & 145 & 100 & 338 & 100 & \\
\hline
\end{tabular}

Source: Survey data, 2017

As it is shown in Table 4.11, the majority (73.1\%) of defaulter respondents and $46.2 \%$ of non-defaulter respondents responded that the repayment period were not suitablewhile, 53.8\% of non-defaulter respondents and $26.9 \%$ of defaulter respondents responded the payment period is suitable. Furthermore, the cross tabulated analysis the $C h i$-square value and significance value $\left(x^{2}=25.22, \mathrm{p}<0.001\right)$ also indicated that repayment period has statistically significant association default risk. Key informants also added that if borrowers find the repayment period appropriate, they can utilize the loan proceeds effectively for the intended purpose than those who regard the period of repayment not appropriate. 
Relationship between borrowing experience and default risk

\begin{tabular}{|c|c|c|c|c|c|c|c|}
\hline \multirow{3}{*}{ Borrowing experience } & \multicolumn{4}{|c|}{ Default Risk } & \multirow{2}{*}{\multicolumn{2}{|c|}{ Total }} & \multirow{3}{*}{$\begin{array}{c}\chi_{\text {Cal }}^{2} \\
\text { (p-value) }\end{array}$} \\
\hline & \multicolumn{2}{|c|}{ Defaulter } & \multicolumn{2}{|c|}{ Non-defaulter } & & & \\
\hline & $n$ & $\%$ & $n$ & $\%$ & $n$ & $\%$ & \\
\hline Once & 190 & 98.4 & 131 & 90.3 & 321 & 95.0 & \multirow{3}{*}{$\begin{array}{c}\mathbf{1 1 . 3 8} \\
(0.001)\end{array}$} \\
\hline Twice & 03 & 1.6 & 14 & 9.7 & 17 & 5.0 & \\
\hline Total & 193 & 100 & 145 & 100 & 338 & 100 & \\
\hline
\end{tabular}

Source: Survey data, 2017

As presented in Table 4.12, the majority (95\%) of borrowers borrowed once and $5 \%$ of them borrowed twice. Out of respondents those borrowed once, $98.4 \%$ of borrowers were defaulters compared to non-defaulters $(90.3 \%)$. Furthermore, from those who had twice borrowing experience $9.7 \%$ of borrowers were non-defaulters compared to defaulters $(1.6 \%)$. The $C h i$-square results $\left(x^{2}=11.38, \mathrm{p}<0.01\right)$ also revealed that borrowing experience and default risk has statistically significant association. The results of key informant interview revealed that experienced borrowers can understand their right and obligation very well; they can be a role model for others who couldn't take the loan. They follow the rules of the microfinance institution. This indicates that those borrowers who had less borrowing experience were more often defaulters than borrowers who had more borrowing experience.

Relationship between alternative source of income and default risk

\begin{tabular}{|c|c|c|c|c|c|c|c|}
\hline \multirow{3}{*}{ Income source } & \multicolumn{4}{|c|}{ Default Risk } & & & \multirow{3}{*}{$\begin{array}{c}\chi_{\text {Cal }}^{2} \\
\text { (p-value })\end{array}$} \\
\hline & \multicolumn{2}{|c|}{ Defaulter } & \multicolumn{2}{|c|}{ Non-defaulter } & \multicolumn{2}{|c|}{ Total } & \\
\hline & $n$ & $\%$ & $n$ & $\%$ & $n$ & $\%$ & \\
\hline No & 181 & 93.8 & 93 & 64.1 & 274 & 81.1 & \\
\hline Yes & 12 & 6.2 & 52 & 35.9 & 64 & 18.9 & $\mathbf{4} / .40$ \\
\hline Tota & 193 & 100 & 145 & 100 & 338 & 100 & \\
\hline
\end{tabular}

Source: Survey data, 2017

Regarding alternative source of income, the majority $(81.1 \%)$ of borrowers had no alternative source of income, where as $18.9 \%$ of them had alternative source of income. Out of the total borrowers who had no alternative source of income, $93.8 \%$ of them were defaulters compared to non-defaulters $(964.1 \%)$. On the other hand, from those who had alternative source of income $35.9 \%$ of borrowers were non-defaulters compared to defaulters $(6.2 \%)$. The $C h i$-square results $\left(x^{2}=47.40, \mathrm{p}<0.001\right)$ also revealed that alternative source of income and default risk has statistically significant association. This indicates that those borrowers who had no alternative source of income were more often defaulters than borrowers who had alternative source of income.

\section{Determinants of loan default in connection with external factors in OMF}

This topic deals with determinants of loan default in connection with external factors in OMF and the results are presents as follows.

Relationship between training and default risk

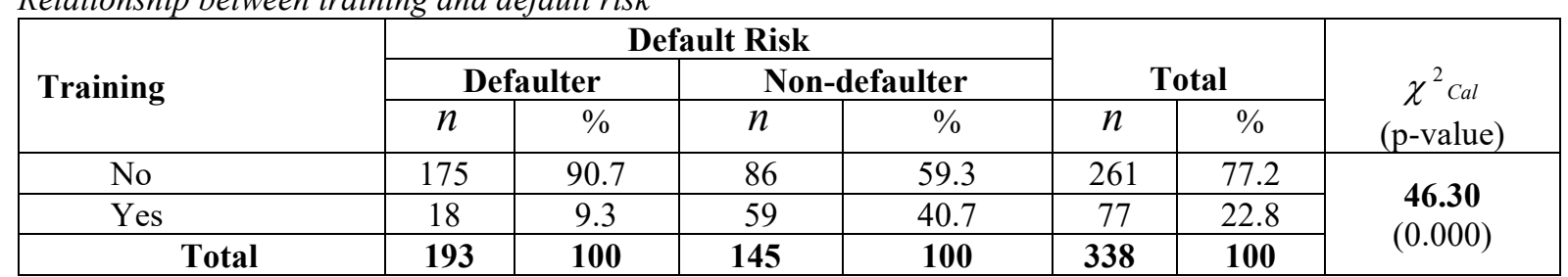

Source: Survey data, 2017

Regarding to training, majority of respondents $77.2 \%$ of respondents indicated that they did not receive training on business and about institutional services during receiving loans, while $22.8 \%$ of respondents responded that received training before receiving loans. Out of respondents those did not receive training the majority $(90.7 \%)$ of them were defaults, whereas $59.3 \%$ of them were non-defaulter. Key informants added that the training was not sufficient to enable the defaulters to apply the skills obtained during the training. Defaulters' that trained only in technical education have high rates of loan default compared to others. This implies that business and entrepreneurship training is vital for borrowers for enhancing borrowers to allocate their loan wisely and efficiently. The results indicate that training borrowers in both technical and business and entrepreneurship reduces the rate of loans default. 
Respondents response on training related issues

\begin{tabular}{|l|c|c|c|}
\hline \multicolumn{1}{|c|}{ Variables } & Categories & Frequency(n) & Percentage (\%) \\
\hline \multirow{2}{*}{$\begin{array}{l}\text { Who offered the } \\
\text { training? }\end{array}$} & Government office & 37 & 48.1 \\
\cline { 2 - 4 } & NGO & 40 & 51.9 \\
\cline { 2 - 4 } & Total & $\mathbf{7 7}$ & $\mathbf{1 0 0}$ \\
\hline \multirow{2}{*}{$\begin{array}{l}\text { How waining } \\
\text { traing }\end{array}$} & Very useful \& well organized & 35 & 45.5 \\
\cline { 2 - 4 } & Useful but not organized & 42 & 54.5 \\
\cline { 2 - 4 } & Total & $\mathbf{7 7}$ & $\mathbf{1 0 0}$ \\
\hline
\end{tabular}

\section{Source: Survey data, 2017}

As presented in Table $4.15,51.9 \%$ of respondents revealed that the training was offered by non-governmental organization, whereas $48.1 \%$ of them trained by government offices. This inferred that the role of the government in offering training is less and this leads to them in difficult situation in proper management of the loan they borrowed and they cannot used appropriately.

Regarding the situation of the training, $54.5 \%$ of respondents responded that the training was useful but not well organized as needed, while below half of respondents reported that the training was very useful \& well organized. Similarly, Omer et al., (2015) stated that short-term training programs can enhance enterprise growth in the same way as human capital does; training expands the scope of profitable business opportunities and provides skills that are necessary to harness business opportunities.

\section{Multivariate analysis on factors affecting the loan performing of borrowers}

This section tries to examine the effect of selected variables which is found to be significant at vicariate analysis. In order to examine the relative importance or net effect of each independent variable, by controlling all the confounding factors, multivariate analysis in a form of binary logistic regression was employed. Before using the model, multicollinearity problem among the independent variables was tested using contingency coefficient and it was found that there was no such problem among the variables. In this study, the dependent variable is loan performing.

Omnibus Tests of Model Coefficients and Model Summary

\begin{tabular}{|c|c|c|c|}
\hline Chi-square & Df & Sig. & Pseudo R Square \\
\hline $169.09 * *$ & 11 & 0.000 & .852 \\
\hline
\end{tabular}

Source: Model output, 2017

The Chi-square result ( $\left.x^{2}=169.09, \mathrm{df}=11, \mathrm{p}<0.001\right)$ from the model summary indicates that the overall model is significant when all independent variables (sex, age, educational level, family size, residence, advisory visit, timelines of loan, repayment period, borrowing experience, permanent income source and training) are entered. The "pseudo" $\mathrm{R}^{2}$ estimates indicates that approximately $85.2 \%$ of the variance in whether the Omo Micro finance borrowers are defaulter or non-defaulter can be predicted from linear combinations of the ten independent variables. Results of Binary Logistic Regression model for the effects of independent variables on loan performing of borrowers

\begin{tabular}{|l|c|c|c|c|c|}
\hline \multicolumn{1}{|c|}{ Variables } & B & SE & Wald & P-value & $\operatorname{Exp(B)}$ \\
\hline Sex & 1.633 & .445 & 13.472 & .000 & 5.119 \\
\hline Age & 0.342 & .238 & 2.063 & .151 & 1.407 \\
\hline Educational level & 0.613 & .184 & 11.086 & .001 & 1.847 \\
\hline Family size & -0.666 & .180 & 13.736 & .000 & .514 \\
\hline Residence & 0.291 & .497 & .342 & .558 & 1.338 \\
\hline Advisory visit & 0.833 & .334 & 6.227 & .013 & 2.300 \\
\hline Timelines of loan & 1.195 & .331 & 13.037 & .000 & 3.304 \\
\hline Repayment period & 1.388 & .338 & 16.865 & .000 & 4.006 \\
\hline Borrowing experience & 2.154 & .844 & 6.513 & .011 & 8.622 \\
\hline Training & 2.141 & .716 & 8.955 & .003 & 8.509 \\
\hline Alternative Income source & -0.960 & .839 & 1.311 & .252 & .383 \\
\hline Constant & -6.278 & 1.269 & 24.473 & .000 & .002 \\
\hline
\end{tabular}

Note: $\mathrm{B}=$ Beta Coefficient, $\mathrm{S} . \mathrm{E}=$ Standard Error

Source: Model output, 2017

According to binary logistic regression output, out of ten variables which were included in the model, even predictors have found to be significant effect on default risk. Since it has no value to present insignificant variables (age, residence and income source of respondents) the following paragraphs describe only significant variables. Sex: - It is evident from Table 4.17 that sex has significant effect on default risk since regression coefficient and $\mathrm{p}$-value $(\mathrm{B}=1.633, \mathrm{p}<0.001)$ in the model. From the values of odds ratio it can be inferred that if the borrower is 
female, the default risk of borrowers will be expected to increase by 5.119 units regardless of other independent variables in the model. More generally, female borrowers can repay the amount of borrowed money than male borrowers in the study area. The findings of Solomon and Addisu (2013) revealed that sex has significant impact on repayment rate. They added that female borrowers were better payers than male borrowers, taking into consideration their being more entrepreneurial that results from assuming more responsibilities in the internal affairs of a household. The study done by Nam and Duy (2016) confirm that women are "better" in repaying loans than men. They explained that women are generally considered to be better borrowers because they are less likely to spend the loans on non-productive expenditure (e.g. cigarettes or alcohol), they tend to be less mobile (e.g. risk to disappear with the money) and they are more likely to spend the money on the well-being of the households (e.g. food and education). Lending to women may open more opportunities for them to handle the household's income-generating activities and lead to their economic empowerment. But the study opposed by the finding of Fikirite (2011) in Addis Ababa male are twice more likely to pay loan than female. The difference in value is, this study finding included urban female borrowers, hence urbanization and related factors may differ value. Therefore, the result indicated that rural women were loyal to microfinance institutions.

Educational Level: It is apparent from Table 4.17that educational level has positive and significant effect on the loan performing of borrowers. The coefficient for educational level is found to be significant at $5 \%$ level of significance $(B=0.613, p<0.01)$. The positive relationship implies that the probability of being non-defaulter increases as a borrower increases its educational level. The odds ratio of indicates that, other independent variables being constant, the likelihood of non-defaulter increases by a factor of 1.847 as capability of proper use of finance a borrower's level of education increased by one unit. This means the borrowers who have higher educational level have lesser chance to be defaulters than borrowers who has lesser educational level. It has been suggested that borrowers with higher educational levels may either increase the capacity to use and repay the loan in time, or increase the probability to know each other in group lending schemes, which results in better screening, monitoring and enforcement within the group. This concurs with the results of Duy and Nam (2016).Supporting this finding Pasha and Tolosa (2014) found out that education level was positively and significantly influencing loan repayment. An increase in one year schooling increases the probability of the loan repayment rate by 4.939 , ceteris paribus. This means borrowers whose educational level increased have the probability of increasing the loan performing four times more than the borrowers who have lesser education level/ illiterates. This suggests that more educated borrower may have access to business information.

Family size: Family size is negative and significant effect on the loan performing of borrowers at acceptable probability level of significance $(B=-0.666, p<0.001)$. The negative relationship implies that when the number of family size increases, the probability of being non-defaulter is decreasing. The implication is that, keeping other independent variables constant, the probability of repaying the borrowed money on time decreased by a factor of 0.514 as the number of family size increases by one unit. This shows that that large family size leads to defaulters. The findings of Ojiako and Ogbukwa (2012) observe negative influence of family size on loan performing for small business owners and farmers in Nigeria. It implies that larger family size exposes high risk of loan default. Similarly, Vasanthi and Raja (2006) observe the negative influence of the number of dependents and the loan default risk for housing borrowers in Australia.

Advisory visit: advisory visit has positive and significant effect on default risk. The coefficient for advisory visit is found to be significant at $5 \%$ level of significance $(\mathrm{B}=0.833, \mathrm{p}<0.05)$. The positive relationship implies that the probability of being non-defaulter increases as a borrower gets visitor. The odds ratio of 2.30 indicates that, other independent variables being constant, the likelihood of non-defaulter increases by a factor of 2.30 as advisory visit increased by one unit. This means the borrowers who got follow up have lesser chance to be defaulters than borrowers who have not got follow up. Supporting this finding Pasha and Tolosa (2014) found out that if other variables held constant, continuous follow up and visit of respondents reduces their probability of being defaulter by 0.102 .

Timelines of loan: - It is observed from the model result that timelines of loan has positive and significant effect on loan performing of borrowers. The regression coefficient and $p$-value $(B=1.195, p<0.001)$ revealed that timelines of loan has significant effect on loan repayment default risk of performance of borrowers and the prediction shows that if timelines of loan increased by one unit the probability of a borrower to repay its loan will expected to increase by 3.304 units regardless of other independent variables in the model. In supporting the finding Fitsum (2014) indicated that borrowers who get the loan less than a month have more likely to repay their loan than borrowers who get the loan greater than one month because, the loan will be diverted to an intended purpose if it is not disbursed in time. The impact is higher in seasonal loans especially agricultural loans.

Repayment period: Repayment period is a factor that affects the loan performing of borrowers in the study area. The result of the regression analysis revealed that this variable was found to be statistically significant at one percent probability level and influences positively the loan performing of borrowers $(B=1.388, p<0.001)$. The positive relationship is explained by the factor that repayment period being a witness for loan performing of borrowers; those borrowers with appropriate repayment period have better chance to repay their loan. The odds 
ratio of the repayment period indicates that other independent variables being constant, the likelihood of borrowers to repay their loan increases by a factor of 4.006 as the repayment period is suitable for borrowers. In connection to this finding Pasha and Tolosa (2014) found out that the arrangements of suitable loan repayment period for borrowers decrease the chance of being defaulter. If borrowers find the repayment period appropriate, they can utilize the loan proceeds effectively for the intended purpose than those who regard the period of repayment unsuitable. In addition Fitsum (2014) also found out that borrowers who perceive the installment period appropriate was increases non defaulter rate by factors of 7.21 times for suitability of installment period than who perceive the period was unsuitable. It is expected that borrowers who find the repayment period suitable, perform better.

Borrowing experience: Borrowing experience is one factor that affects the loan performing of borrowers in the study area. As expected, borrowing experience was found to be positive and statistically significant association with the loan performing of borrowers $(B=2.154, \mathrm{p}<0.05)$. The result showed that the probability of repaying increases by a factor of 8.622 as borrowing experience increased by one unit. In connection to this finding Magali (2013) explained that year of borrowing experience reduce the risk of loan default since the borrowers have accumulated enough skills and experiences that could help them to manipulate business environments to prevent the loans default. Similarly, Sileshi (2014) found out that the borrowers who had more experience with formal credit from the same institute/different institute were more likely to repay their loans than, those with less credit experience.

Training: this variable was also found to influence positively and significantly the borrowers' loan performing at $1 \%$ significance level. If other variables holds constant the delivering of well-organized and sufficient training properly for borrowers increase the probability of being non-defaulter by 8.509 units.In the same way, Ledgerwood(2010) found that small and medium enterprise owners with business training have higher level of assets and sales revenue compared to their counterparts in Tanzania. It implies that borrowers with training skills manage to utilize their capital effectively because of the skills gained.

\section{Conclusions}

Credit provision in microfinance is a risky business for a lender as it may be negatively affected by duplicitous and opportunistic behavior of the borrowers. Omo microfinance institution borrowers in Hawassa were challenged by defaulters. The borrowers start to pay but failed to continue due to low income, unprofitability from their business and use of loan for other consumption purpose.

The major factors that affect the loan performing of Omo microfinance institution borrowers were sex of the borrower, educational level, family size, advisory visit, time lines of loan, repayment period, borrowing experience and training. Females are generally considered to be better borrowers because they are less likely to spend the loans on non-productive expenditure, they tend to be less mobile and they are more likely to spend the money on the well-being of the households. Lending to women may open more opportunities for them to handle the household's income-generating activities and lead to their economic empowerment. Borrowers with higher educational level may either increase the capacity to use and repay the loan in time, or increase the probability to know each other in group lending schemes, which results in better screening, monitoring and enforcement within the group. Borrowing experience reduce the risk of loan default since the borrowers have accumulated enough skills and experiences that could help them to manipulate business environments to prevent the loans default. Timely received loans increase the repayment performance otherwise the loan will be diverted to an intended purpose if it is not disbursed in time. The impact is higher in seasonal loans especially agricultural loans. Continuous follow up and visit makes borrowers to observe their obligation and improve the proper utilization of the loan thereby reduces their probability of being defaulter.

\section{Recommendations}

There is no doubt that understanding the problem and forward the following possible recommendations for microfinance institutions in general and Omo microfinance institution borrowers in Hawassa project office particular will shed light to service the financial needs of un-served markets as a means of meeting development objectives such as to create employment, reduce poverty, help to develop existing business or diversify their activities, empower women or other disadvantaged population groups, and encourage the development of new business. Consequently, based on the identified factors that affect the loan performing of borrowers, the researcher forwards the following possible recommendations:

- Female borrowers have performed better in terms of loan repayment than their male counterparts but, the number of women being served particularly in the rural parts of the sub city is very small. Therefore, the institution should encourage women borrowers.

- Educational levels have positive impact on loan performing of borrowers. Literate borrowers are better loan repayment rate than illiterates'. Such borrowers did not receive formal education and are likely to have inadequate knowledge of loan acquisition and management, thereby making them unable to repay 
the loans. Therefore, the institution should provide short and long term awareness creation training for illiterate borrowers and motivate educated people because it is easy to provide training.

- The complicated loan processing procedures, which might lead to delay in disbursement, further, it will increase default rate. Therefore, the institution should reduce the time lag between loan application and disbursement to increase repayment rate.

- Repayment period is also found to be a significant determinant of loan performing of borrowers. Therefore, the institution should revise loan installment period and expand collection period, so some loan financed activities require more than a year to get a return from investment and others may require short period to get return on investment, a flexible repayment period should be designed in order to improve the existing default rate such as; - for agricultural loan on farm time.

- Advisory visit has effect on loan performing of borrowers. Therefore, the institution needs to make sure that borrowed funds are being used for the intended purpose through enhanced timely credit monitoring after the loan is being disbursed. In order to develop effective credit rationing system, credit committee members are recommended to visits borrower's business premises, verify borrower's asset collateral and enquire borrower's additional information during screening process so as to ensure that only credit worthy borrowers are granted loans.

\section{REFERENCES}

Arsyad, L.(2005). An assessment of Microfinance Institution performance: The Importance ofInstitutional Environment‘. GadjahMada International Journal of Business, 7(3), 391-427

Asanty, J.O., \&Tengey, S. (2004). An empirical study on the effect of bank loans on Bank lending potential and financial performance: The case of SME lending in Ghana. International Journal of Research in Business Management.

Babouchek, I., and Jancar, M. (2005).Effects of Macroeconomic Shock to the Quality of the Aggregate Loan Portfolio. Czech National Bank Working Paper Series, 1,1-62.

Basel Committee. (2001). Sound Practices for the Management and Supervision of Operational Risk. Basel Committee on Banking Supervision.

BoFED.(2016). Annual statistical data magazine, Bureau of finance and Economic Development of Hawassa City Administration.

Cochran, W. (1977).Sampling Technique.3rd Ed. New York: John Wiley and Sons.

Creswell, J.W. (2009). Research Design: Qualitative, Quantitative, and Mixed Methods Approaches. 3rd ed. London: SAGE Publications, Inc.

Duy, V.Q., and Nam, M. V. (2016). Determinants Repayment Performance Of Borrowers In Rural Mekong Delta Of Vietnam. IJISET - International Journal of Innovative Science, Engineering \& Technology, 3(1). ISSN $2348-7968$.

E.R. Yescombe .(2014). Principle of Project Finance. Elsevier, Chapter 2.

Enzo, S. (2012). Bank Lending in Project Finance: The new regulatory capital framework, International Journal of Economics and Finance, 5(1).

Facet, T. (2013).Policy Review and Private Sectors Development: Country Report of Ethiopia, January 2013, Netherlands.

Faical, B. (2014).Loan Quality determinants: evaluating the contribution of bank- specific variables, macroeconomic factors and firm-level information. (Working paper).Central Bank of Tunisia.

FikirteReta. (2011). Determinants of loan Repayment Performance: A case study in the Addis Credit and Saving Institution, Unpublished Master's Thesis. Wageningen University, Netherlands.

FitsumTadele. (2014). Determinants of Microfinance Loan Repayment Performance: Case of Omo Microfinance (OMF) in Kaffa Zone. Unpublished Masters' Thesis, Jimma University, College of Business and Economics Department of Accounting and Finance, Jimma.

Fuentes, R., \&Maquieira, C. (2003). Institutional arrangements, credit market development and loan repayment in Chile, School of Business and Economics, Universidad de Chile.

Gatimu., Eric., and Frederick. (2014). Assessing Institutional factors contributing to loan default in microfinance institutions in Kenya, IOSR Journal of Humanities and Social Science, Vol-19,Ver-II.

Geanakoplos, J. (2009). The Leverage Cycle. Cowles Foundation. (Discussion Paper No. 1715).

HCAFDD. (2016).Socio- Economic and Geo-Spatial Data Analysis and Dissemination core work process, Hawassa Ethiopia. Mirror printing PLC.

International Monetary Fund.(2009). Initial lessons of the crisis. (IMF Staff Paper 09/37). International Monetary Fund: Washington, DC.

Kalirai, H., \& Schleicher, M. (2002). Macroeconomic Stress Testing: Preliminary Evidence for Austria. Austrian National Bank Financial Stability Report, May, no. 3.

Khushbu, A. (2014). Default Risk Modeling using macroeconomic variables. Journal of Indian Business Research, 
Vol-6, Pp. 270-285.

Kothari, C.R. (2012). Research Methodology-Methods and Techniques, New Delhi: Wiley Eastern Limited.

Ledgerwood, J. (2013). A Financial Market System Perspective: The New Microfinance Handbook. Washington, DC: World Bank.

Leedy., and Ormrod. (2005). Qualitative type Research design: interpretative, and postositivist approach.Retrieved May 2, 2017, from inform.nu/Articles/Vol11/ISJv11p017-033Ellis486.pd.

Mabrure, T., Gwangwara, E., Fajitira, M., Mutibvu, C., and Kamyo, M. (2012). Non-performing loans in Commercial Banks; A case study of CBZ bank limited in Zimbabwe. Interdisciplinary Journal of Contemporary Research in Business, 4(7).

Magali, J.J. (2013). Factors Affecting Credit Default Risks For Rural Savings and Credits Cooperative Societies (SACCOS) in Tanzania. European Journal of Business and Management, 5(32), ISSN 1222-1905.

McKerchar, M. (2010).Design and conduct of research in tax, law, and accounting. Sydney: Thomson Reuters. Retrieved May 28, 2017, from http: //www.cgapdirect.org.

Nawai, N., and Shariff, M. (2010). Determinants of Repayment Performance in Microcredit Programs: A Review of Literature. International Journal of Business and Social Science, 1(2), 93-99.

NBE.(2008). Asset classification and Provisioning Directive No.SBB/43/2008.National Bank of Ethiopia. Addis Ababa, Ethiopia.

Neila, B. (2014). Project Finance: Determinants of the Bank Loan Spread. International Journal of Business and Social Science, 5(5).

Nguta, M.H., and Huka, G. (2013). Factors Influencing Loan Repayment Default in Micro-Finance Institutions: The Experience of Imenti North District, Kenya. International Journal of Applied Science and Technology, $3(3), 80-84$.

Ojiako, I. A. and Ogbukwa, B. C. (2012), Economic Analysis of Loan Repayment Capacity of Smallholder Cooperative Farmers in Yewa North Local Government Area of Ogun State, Nigeria. African Journal of Agricultural Research, 7(13), 2051-2062.

OMFI.(2016). Omo Microfinance Institution five years (2008-2012 E.C) strategic plan. Hawassa, Ethiopia.

Pasha.A.M., and Tolosa, N. (2014). Performance of Loan Repayment Determinants in Ethiopian Micro Finance. Eurasian Journal of Business and Economics, 7 (13), 29-49.

Patersson, J., \&Wadman, I. (2004). Non- Performing Loans-The markets of Italy and Sweden, Uppsala University thesis, Department of Business Studies.

Patnik, B. (2011). NPA Side Effects and Creative Mantra. International Journal of Research in Commerce \& management.

Salas, V., \&Saurina, J (.2002). Credit Risk in Two Institutional Regimes: Spanish Commercial and Savings Banks. Journal of Financial Services Research, 22(3), 203-224.

SileshiCherkos. (2014). Loan Repayment Performance of Farm Households: The Case of Omo Microfinance in SoddoZuria District of Southern Ethiopia .Unpublished Masters' Thesis, Haramaya University, School of Agricultural Economics and Agribusiness, Haramaya.

SololomonAlemu and AddisuBajira. (2013). Determinants of Rural Households Loan Repayment Performance, In Oromia National Regional State: The Case of Dodota Woreda. International Journal of Research in Computer Application \& Management, 3(11).

Sorge, M. (2004).Stress- Testing Financial systems: An overview of current methodologies. Bank for International settlements.(Working paper, No.165).

Waweru, N.M., \&Kalani, V. M. (2009). Commercial banking crises in Kenya: causes and remedies. African Journal of Accounting, Economic Economics, Finance and banking research, 4(4), 12-32

WondemagegnehuNegera. (2012). Determinants of non-performing loans: The case of Ethiopian Banks, partial fulfillment of Master's degree program in Business leadership, UNISA.

Zinat, S. A. (2010). An empirical analysis of the determinants of Project Finance: Cash flow volatility and correlation, Finance dissertation, Georgia state university. 